\title{
SITUATING WOMEN SCIENTISTS WITH NON-NORMATIVE GENDER POSITIONS IN THE COLOMBIAN NATIONAL SYSTEM OF SCIENCE AND TECHNOLOGY
}

\author{
TANIA PÉREZ-BUSTOS*, ANDREA GARCÍA-BECERRA \\ PONTIFICAL XAVERIAN UNIVERSITY, FACULTY OF SOCIAL SCIENCES, \\ DEPARTMENT OF ANTHROPOLOGY, BOGOTÁ, COLOMBIA
}

Recibido, septiembre 1/2013

Concepto evaluación, octubre 2/2013

Aceptado, noviembre 20/2013
Referencia: Pérez-Bustos, T. \& García-Becerra,A. (2013). Situating women scientists with non-normative gender positions in the Colombian national system of science and technology. Acta Colombiana de Psicología, 16(2), 47-54.

\begin{abstract}
Gender and science studies in Latin America have questioned the unequal structures of the scientific field in the region using as analytical pivot a particular and homogeneous idea of women scientist as opposed to men scientist. From these analytical approaches aspects such as ethnicity, race and sexuality, which are central to the shaping of the feminine condition as something marginal to the scientific field, have become invisible. In this study we focus on the case of Colombian women scientist whit non-normative gender positions shaped by experiences of racialization such as being black or indigenous, or experiences of minoritization in relation to their sexuality such as being lesbian, with the purpose of analyzing their narratives of self-positioning in relation to the Colombian national system of science and technology. Methodologically these narratives were collected through ethnographic interviews to 19 women scientists from different regions of the country. The results reveal that science and technology fields are gendered in ambiguous ways. The study concludes that these women scientists see themselves as marginal to the structure of prestige that characterizes the system; but they also position their work by acknowledging that their minority marks reshape the scientific ethos through a particular ethics of care.

Key words: women scientists, ethnicity, race, sexuality, care, significant bounderlands
\end{abstract}

\section{SITUANDO A CIENTÍFICAS CON POSICIONES DE GÉNERO NO NORMATIVAS EN EL SISTEMA NACIONAL DE CIENCIA Y TECNOLOGÍA COLOMBIANO}

\author{
Resumen
}

\begin{abstract}
Los estudios de género y ciencia en América Latina han cuestionado las estructuras inequitativas del campo científico tomando como principal eje de análisis una cierta idea homogénea de las mujeres científicas en oposición a sus colegas varones. Desde estas lecturas se han vuelto invisibles cuestiones étnico-raciales y de sexualidad que también configuran el lugar marginal de lo femenino en la ciencia. El estudio se centró en el caso de científicas colombianas con posiciones de género no normativas, particularmente marcadas por experiencias de racialización, como el ser negras o indígenas, o por experiencias de minorización en relación con su sexualidad, como el ser lesbianas, con el propósito de analizar sus narrativas de auto-posicionamiento frente al sistema colombiano de ciencia y tecnología por parte de estas científicas. Metodológicamente, estas narrativas fueron recogidas a través de entrevistas de carácter etnográfico a 19 científicas en diferentes regiones del país. Los resultados obtenidos revelan que el campo científico está atravesado por el género, de manera ambigua. El estudio concluye que estas científicas se perciben al margen de la estructura de prestigio que caracteriza al sistema de ciencia, pero también posicionan su trabajo reconociendo que sus marcas minoritarias reconfiguran el ethos científico a través de una ética del cuidado particular. Palabras clave: mujeres científicas, etnia, raza, sexualidad, cuidado, fronteras significativas.
\end{abstract}

\footnotetext{
* Dirigir la correspondencia a la primera autora, Facultad de Ciencias Sociales, Cra. 5, no. 39-00, Edificio 95, piso 3, Bogotá, Colombia,
} Tania Pérez Bustos: tpbustos@gmail.com y Andrea García Becerra: andreagabecerra@gmail.com 


\title{
SITUANDO CIENTISTAS COM POSIÇÓES DE GÊNERO NÄO NORMATIVAS NO SISTEMA NACIONAL DE CIÊNCIA E TECNOLOGIA COLOMBIANO
}

\author{
Resumo
}

\begin{abstract}
Os estudos de gênero e ciência na América Latina questionaram as estruturas desiguais do campo científico tomando como principal eixo de análise uma certa ideia homogênea das mulheres cientistas em oposição a seus colegas homens. Desde estas leituras permaneceram invisíveis questões étnico-raciais e de sexualidade que também configuram o lugar marginal do feminino na ciência. $\mathrm{O}$ estudo centrou-se no caso das cientistas colombianas com posições de gênero não normativas, particularmente marcadas por experiências raciais, como a de ser negras ou indígenas, ou pelas experiências de minoria com respeito à sua sexualidade, como ser lésbicas, com o propósito de analisar suas narrativas de autoposicionamento diante do sistema colombiano de ciência e tecnologia por parte destas cientistas. Metodologicamente, estas narrativas foram coletadas através de entrevistas de caráter etnográfico a 19 cientistas em diferentes regiões do país. Os resultados obtidos revelam que o campo científico está atravessado pelo gênero, de maneira ambígua. $O$ estudo conclui que estas cientistas se percebem à margem da estrutura de prestígio que caracteriza o sistema de ciência, mas também posicionam seu trabalho reconhecendo que suas marcas minoritárias reconfiguram o ethos científico através de uma ética do cuidado particular.

Palavras chave: mulheres cientistas, etnia, raça, sexualidade, cuidado, fronteiras significativas.
\end{abstract}

\section{INTRODUCTION}

It's been thirty years already since feminist studies were discussing the mechanisms through which science and technology fields are shaped by gender (Fox-Keller, 1985; Haraway, 1988; Harding, 1986; Schiebinger, 1999). One of the main findings of these studies is that the production of scientific knowledge is marked by androcentric norms and values, which privilege the establishment of an ethos based on competitiveness, emotional detachment and universality, among other things (Rhoton, 2011). Following Haraway (2004), we understand that these gendered norms are crosscut by race, class and sexual orientation, and so are anchored to a certain hegemonic representation of masculinity, particularly one that emerged in the seventeenth century with the origins of what we now know of as science, namely a white, modern and European masculinity.

To discuss the implications of the cultural paradigms that characterize science, feminist scholars in Ibero-America have focused their studies on the question of women in science. Some have worked on making visible the presence of women in various fields (Blasquez Graff \& Flores, n.d.; García Dauder, 2005; Magollón Porales, 2004; Pérez Sedeño, 2011). Others have studied the underrepresentation of women in masculinized areas (Daza-Caicedo, 2010; Fernández Ruiz, 2006; Tovar, 2006; Vessuri \& Canino, 2006). This emphasis aims to address gender inequality within national systems of science and technology. However, it also contributes to the non-recognition of other types of diversities and power relations within these systems (Pérez-Bustos, Olarte Sierra \& Diaz del Castillo, forthcoming). In this sense, the studies undertaken in the region have helped to build a homogeneous idea of women scientists as the radical other of men scientists; namely, a white heterosexual woman ${ }^{1}$.

Looking to problematize this gendered binary, we propose to analyze how women scientists with lesbian or racialized experiences of their femininity ${ }^{2}$ narrate the position they perceive themselves to have within the scientific field. We understand these narratives altogether as a heterogeneous representation of the borderlands that shape this territory. In this sense, we argue that in order to transgress gender binaries, it is necessary to approach diversity with caution regarding potential essentialisms in relation to race and sexuality. Thus, we do not see each of these women scientists as part of closed population groups, but as particular voices that allow us to hear the emergence of cracks within the aforementioned normative scientific ethos.

\footnotetext{
1 On one hand, these studies assume (unintentionally) that the experience of white-mestizo women is representative of the experience of women in general, something that Adriane Rich called white solipsism: the tendency to "think, imagine, and speak as if whiteness describes the world" (in Mikkola, 2006:80). For the case of science, it implies that conclusions about women pioneers' experiences in certain scientific fields, for example, are extensible to black or indigenous women scientists. On the other hand, these studies widely discuss how gender barriers in science are particularly shaped by the double burden that women scientists bear when they have to combine their career with their role as mothers and wives. This assumption presupposes an idea of women who have a heteronormative sexuality, and thus does not represent the particular burdens that lesbian women, in their diversity, have to bear within the scientific field (McKenzieBassant, 2007; Williams, 2013)

2 We focused on three groups of women scientists: women who recognize themselves as lesbian in various ways; women who identify themselves as indigenous; and women who are racialized as black.
} 


\section{METHOD}

\section{Participants}

The study took as its starting point a referral sampling exercise to identify lesbian, black and indigenous women scientists working in public and private universities in different regions of the country ${ }^{3}$. Such a methodological approach is suitable for identifying hidden populations (Platt et al., 2006), which is the case for these women scientists, considering that the scientific information system in Colombia does not take into consideration sexuality or race as qualifiers of its researcher population.

\section{Sampling procedure}

Sampling began with a set of women scientists known by the research team, and who recognize themselves as lesbian, black or indigenous ${ }^{4}$. We also interviewed experts in gender, Afro-Colombian and indigenous studies, and asked them to provide new names. The initial references served as seeds for expanding the chain of referrals. Through this method, we were able to identify a total of thirty-one women scientists: eight lesbian, five indigenous and eighteen black.

\section{Measures and Research Design}

After the identification, we proceeded to contact these women to inform them about the goals of the study and our policies of confidentiality. We also asked them to confirm their self-designation as black, indigenous or lesbian, and their affiliation as researchers within institutions recognized by Colciencias 5 . Finally, we asked them for their interest to be part of the study. We were unable to get in touch with all of the women to conduct in depth interviews. In the end, we interviewed a total of nineteen women scientists: five lesbian, two indigenous and twelve black.

The purpose of the interviews was to establish a conversation with these women scientists, through which they could narrate how they see their position within the scientific field and describe the relationship between their research careers and their sexuality and racial marks. These conversations allowed us to reflect with them upon their ways of doing science and the purpose of being scientists marked and, on occasion, minoritized by race and sexuality. Through these explorations, we were able to identify their motivations and expectations with regards to the future.

Two particular trends were identified throughout the interviews. First, in close dialogue with what we discussed in the introduction, these women scientists situate themselves in the borderlands of science, an arena that they see as highly hierarchical and biased to privilege certain themes and ways of behaving; a power configuration that particularly affects them and their marks but that goes beyond them. Second, they perceive that this normative structure does not usually recognize their interests and ways of doing science, which are oriented towards transforming the reality of communities (non-scientists). We argue that these two trends are examples of matters of care in science and technology (Puig de la Bellacasa, 2011).

\section{RESULTS}

\section{The boundaries of science}

My job is to locate the periphery in the center. (Ursula, black woman, social scientist)

During the interviews, the black, indigenous and lesbian women scientists mentioned that they see their research work as located in the borderlands of the scientific field, wherein, through their practice, they attempt to build relationships and bridges between the scientific field (Bourdieu, 2008) and other social arenas, such as the territory of social struggles (Archila Neira, 2003) or the political or bureaucratic field (Bourdieu, 1997) ${ }^{6}$. When asked about these practices, they referred to various communicative approaches that give sense and meaning to academic work, but which are not always central to the scientific ethos.

In their testimonies, the borderlands of the scientific field are not only seen as margins. They are action and linkage spaces between universities -as territories of knowledge production- and the social problems, struggles and needs faced by concrete communities, particular regions and certain ecosystems; thus we have call them significant borderlands. This concept is close to what feminists such as Donna Haraway (2004) have elaborated upon when

\footnotetext{
3 Scientists are identified by Colciencias, the national department of science and technology, as researchers registered in its information system. For 2010, 90.68\% of researchers were linked to public and private universities (Observatorio colombiano de Ciencia y Tecnología, 2011).

4 We found only one case of intersection between these markers of difference: a black lesbian woman scientist. All of the others identified themselves as only one of the three (lesbian or black or indigenous).

5 The Colombian national department of science and technology.

6 We refer here to social arenas and activities that exceed the scientific or academic field (communicative practices of different type: pedagogical, consultancy, community based work) and that are symbolically located in its margins. As we will discuss later those borders of the field are also places where scientists such as the ones we studied may situate their practice. This positioning gives peculiar meanings to the borderlands of science. We call this significant borderlands.
} 
speaking of cyborgs as entities that reconfigure and question the notion of humanity, technology and nature. It also dialogues with the concept of borderland as elaborated by Glora Anzaldúa (1987), when she theorized the experience of mestizo women in the United States.

The significant borderlands that we found in the narratives of the interviewed women scientists connected the scientific field with the struggle of ethnic communities, with the demands of sexual rights organizations and with complex environmental regional processes. One of the women scientists at a university in the pacific region of the country said: "Being part of the Afro-Colombian social movement of black women, I cannot give credit to the division between activist and intellectual work. I see that as a western dualism that does not represent what I do. I'm both" (Ines, black woman, social scientist). Another scientist working in a university located in a poor and highly bio-diverse region said: "Mywork [on medicinal plants] cannot be focused on producing knowledge. I have to transmit that knowledge to the communities" (Clara, black woman, natural scientist). Meanwhile, one indigenous woman scientist perceived her research work as connected to her ethnic experience: "We need to build theories that allow us to go beyond western thought, to break dichotomies between science and traditional knowledge. The scientific system is very closed" (Alicia, indigenous woman, educational scientist). From the scientific positioning of a lesbian scientist, these borderlands are spaces in which to build activism towards sexual and gender diversity: "We need to connect activism and academia. We have to work to build a scientific field that is more connected with what is outside of it. To break the ivory tower metaphor that is at its roots, we have to mock it" (Milena, lesbian woman, cultural scientist).

These boundaries that connect the scientific field with other social arenas have an important cultural and symbolic function, in that sense they are significant. They give subjective and objective meaning to the work of these women scientists; indeed, we could say that these boundaries are significant borderlands since they offer justifications and give value to the research that these women scientists develop and perform. This happens not only to those women scientists who are located on the margins of the system, but also those who are at its center. One woman scientist, working at one of the most prestigious universities in the country, affirmed this: "Indeed, the topics I do research about have never been canonical. In this sense, even though I am in the center, I never feel that I have embodied it. In this sense, my work is to locate the periphery in the center." (Ursula, black woman, social scientist). Another scientist who occupies a managerial position referred to how she works to bring the borderlands she embodies to the center of the academic institution, using the possibilities that this scenario offers: "I've been a big user of that center. I use it for activism because I can. I use my power for good [laughs]. Having power is strategic. I know that when I go out and speak, people perhaps believe me, because I'm the director of a department in a prestigious university" (Milena, lesbian woman, cultural scientist).

These words resonate in the voice of an indigenous scientist who occupies a more marginal position within the Colombian system of science and technology ${ }^{7}$. She mentioned that her research is meant to build intercultural relations: "We used to think that not being part of the system strengthens our culture. Nowadays we know we have to combine. We need to create an intercultural science" (Alicia, indigenous woman, educational scientist).

These testimonies show us how, for these women scientists, their practices and doings in the borderlands of the scientific field are central to their work; they justify and give value to their role as scientists. For many of them, their research is meaningful when it can be transmitted to communities, when it plays an empowering role aimed at social transformation, when it is oriented towards the needs of their regions and the ecosystems they inhabit.

It is also interesting to see how many of these scientists are located in explicitly marginal areas of the system. Sometimes this marginal location is seen as related to their racial, sexual or gender marks; on other occasions, it is related to the themes of their research ${ }^{8}$. They consider their areas of work to be less important in relation to what the system promotes or privileges, in the sense that the system does not allocate a great deal of funds to certain areas, such as gender, racial and sexuality studies. This location, however, is often perceived by these scientists as strategic because it allows their borderland work to flourish. As one black woman scientist stated:

Ines: Being in the margins of the system gives me the freedom that I would not have if I were in the center.

Tania \& Andrea: Why do you say you are in the margins? Ines: Because of the kind of research I do [gender stu-

\footnotetext{
7 Her institution occupies position number eighty-three in the Colombian ranking (SCImago, 2012).

8 This positioning which in occasions exceeds their racial and sexuality marks, might allow to link the narratives of these women scientists with the way other scientists reflexively position themselves towards certain issues; we refer here to scientists whose marks are not subordinated and so are seen as part of the normality (heterosexual scientists and scientists racialized as mestizo or white), This would be the case of feminist scientists for example
} 
dies]. It does not represent profit to the system. And so there is always little money for the social sciences. In this sense, the system always places me outside of it. However, being here one is better. Do I want to be at the center? Do I want to be included? In a system that does not give value to what I do? What for? I do not care to be part of it. (Ines, black woman, social scientist) Another lesbian scientist said: "For many people, what I do in the field of public policy has no value in the academic field. The same happens with having work with community radio and video. For me, of course, it is valuable, it is a way to situate myself trans- and interdisciplinarily" (Carla, lesbian woman, anthropologist).

Many of the scientists we worked with do not recognize themselves as scientists. This form of non-scientific identification is related to the scientific ethos mentioned earlier, since they understand science as a process of knowledge production characterized by distancing and competitiveness, which is mainly oriented only to promote expert-expert dialogue. In this context some of them say "I do not feel like a scientist, especially if science is a neutral and objective endeavor" (Ines, black woman, social scientist). "I think I suck as an anthropologist, I am not perceived as a scholar in this field" (Carla, lesbian woman, anthropologist). The women with whom we worked see themselves as scientists only in terms of a close and constitutive relationship with various forms of activism, political participation and cultural or artistic intervention. They distance themselves from the definition of a scientist that is exclusively devoted to academic work as the only way to produce scientific knowledge; distancing that in any case is not essential or exclusive to them as scientists, but that in their narratives take particular shapes and meanings.

\section{Thinking and doing with care}

In what I do and think there are caring practices. (Carla,

Lesbian woman, anthropologist)

In the women scientists' narratives about boundaries, we found that there was a constant reference to the concept of care, to an ethical and political dimension of care in the doing of science (Puig de la Bellacasa, 2011), which meant a sort of search for thinking with care about the world and creating alternative modes of relating with others and knitting interdependencies (Puig de la Bellacasa, 2012). From this perspective, the world does not simply consist of beings who are objects to be known through scientific knowledge, or entities meant to be categorized, described and analyzed.

Care has been considered by numerous feminist perspectives. Care as work, the professions of care, the care economy, the ethics of care (Arango Gaviria, 2011), and care and subordination (Molinier, 2012) are some of the definitions and concepts that appear in the debates ${ }^{9}$. Care is generally related to subordinate positions, for example naturalized invisible and unpaid tasks performed by (poor and/or racialized/migrant) women in domestic and private spaces (Carrasco, 2001; Castro Romero, 2011). It has also been studied when looking at care professions (i.e. nursing and social work) and their lower rank in the general order of professions and disciplines (Molinier, 2011; Mosquera Rosero-Labbé, 2006, 2011). Trying to step out of the social, economic and political location that feminist theory has given to care, we wanted to think of this concept in an area that has a higher social status, such as the scientific field.

From a feminist perspective, the category of care has been associated with science through conceptualizations that consider the ethical-political dimensions of care in the ways in which scientists think of and represent the world, but also how they try to explore careful ways of doing science with a particular relationship to the future (PérezBustos et al., forthcoming; Puig de la Bellacasa, 2011). From this perspective, the idea of thinking with care has been developed (Puig de la Bellacasa, 2012). Thinking with others and thinking collectively are seen as ways to generate interdependencies that question and have the potential to transform the knowledge relationships that hold structures of power in science, to explore the ways in which scientists represent the world, and to investigate the applications of science beyond the scientific field.

In the narratives of the women scientists we worked with, they seem to do and think science with care. A great deal of their work is directed towards caring for racialized communities, ecosystems in danger, sociopolitical agendas, and even their own scientific institutions (i.e. universities). We suggest that for these women scientists, being in the borderlands of the scientific field -as we argue they areenables them to develop such caring practices. On occasion, these narratives reflect a sort of essential idea of caring associated with womanhood:

We as women care for others, I have no doubt about it ... men too, but it is expected of us to be caring. We bring this to the academy. I am aware if the professor

9 We focus here on these perspectives, but acknowledge the existence of other theoretical developments on the concept of care, among them the work of Foucault in relation to care of the self (Foucault, 1994) and theoretical approaches in nursing (Leininger, 1996; Morse, Solberg, Neander, Bottorff \& Johnson, 1990). 
in the office next to mine had lunch. I am in constant solidarity with my black students. I ask them what they need, how they are doing at school. It is a political and ethical commitment that I have acquired. (Ángela, black woman, social scientist)

Another lesbian woman scientist referred to her research in the borderlands as something unrecognized but highly emotionally rewarding:

When I connect my research with my teaching, I connect research with the world. It generates a particular relationship with my students, it makes my research a responsible practice. However, the remuneration for teaching is terribly low, considering the hard work and the craft involved in making these bridges possible; even more when considering that it involves emotional work. It is not a coincidence that teaching is nowadays a female occupation, which is also undervalued in a research career." (Carla, lesbian woman, anthropologist) Feminist theories on the care economy have highlighted the unrecognized and invisible status that caring practices have. They are also seen as extra labor, which has to be undertaken by women since they are culturally shaped as the legitimate caregivers. From the narratives of these women scientists, it seems that this feminization and invisibility is also present in the scientific field.

Care in the connection between teaching, doing service and research

I do a little bit of everything ... It's all connected ... teaching, research and service. (Lilian, indigenous woman, social scientist)

The data obtained in this research has allowed us to think of the importance of categories such as borderlands and care in the scientific work of black, indigenous and lesbian women scientists in Colombia. We have also found that the practices of the production and circulation of scientific knowledge in the borderlands - which connect the scientific field with other social arenas- and the will to think and do science with care -an attitude which is present in their narratives- propose a relationship between teaching, research and service that defines in particular ways the structural ideal of universities today and hence an important part of the scientific field ${ }^{10}$.

In the narratives of these women scientists, the linkage between teaching and scientific research is constant. For them, the classroom is perceived as an important space in which to transfer knowledge in multiple ways; but it is also a space for collective and social transformation: "In the classroom, I want my students to deepen their political sense, but I also deepen it with their life experiences" (Inés, black woman, social scientist). The relationships between scientists and students, the methodologies used for teaching, and the content worked on in classrooms establish communication and knowledge bridges, which train students on issues such as gender, sexuality, race, ethnicity, difference, social struggles, care for the environment and regional development. Addressing these and other issues in the classroom is a political practice of recognition and social transformation; it is also a practice for establishing relationships with communities and for producing scientific knowledge:

It is easier for some students to approach or want to work with me. It's easier to work, for example, on issues of sexuality with me. (Milena, lesbian woman, cultural scientist)

I worked with indigenous communities before becoming a social scientist at the university; that is an experience I try to put in the classroom as well. (Lilian, indigenous woman, social scientist)

Research thus consistently appears as a practice related to teaching and to work with social movements and communities directed towards social transformation processes. For some of these women scientists, research is related to biodiversity, economic empowerment and regional development. All of them were emphatic about questioning research processes that are only meant to strengthen the scientific field in itself; in other words, knowledge that is limited to lab work or research groups, and forms of publication and dissemination of knowledge that only circulate between scientists. For these women scientists, research makes sense when it knits relationships outside of the scientific field, when it is directly linked to communities and to practices of social transformation.

[My] research shall recognize traditional knowledge, and propitiate entrepreneurial projects for communities that are directed towards their well being. (Marta, black woman, natural scientist)

Knowledge has to impact society. Students have to be aware of that responsibility. (Andrea, lesbian woman, engineer)

Scientific knowledge cannot be produced only to strengthen science. It has to benefit people, concrete communities. (Alicia, indigenous woman, educational scientist)

Relationships with communities, with social groups, with the environment and with social struggles, as discussed throughout this paper, shape and are shaped by the work of these women scientists; work which is crosscut by research, teaching and service. We have argued that these bridges are particular representations of a caring science that takes place in the borderlands of the scientific field.

10 Since, as stated in footnote 5 above, the vast majority of scientific research in the country takes place in universities. 


\section{DISCUSSION}

We started this paper with the leitmotif of questioning some of the potential biases within traditional studies of gender and science. In particular, we wanted to point to the binaries that are found in some critiques of science and technology; binaries which are sometimes based on a homogenous idea about womanhood as the radical other in the scientific field. Advocating for gender equity, but not considering that gender is co-constructed by race and sexuality, is not only naïve but also problematic. With this paper we therefore hope to contribute to a more complex questioning of gender in science, taking diversity as non essentialist starting point.

By using the narratives of women scientists holding non-normative gender positions (racialized as black or indigenous, or marginalized because of their sexuality as lesbian) as the main empirical source of the study, we were able to identify two particular trends in terms of how these women scientists see themselves: how they regard themselves as scientists in relation to the national system of science and technology, and how they describe their research in contrast to what the system recognizes and values ${ }^{11}$.

In the first place, we found that these women scientists, in their diversity, situate themselves in the borderlands of the scientific field. Through their narratives, borderlands become ambiguous metaphors. On the one hand, these women scientists represent incarnate the marginality of the topics that they conduct research on, as do their precarious work conditions, especially when they work in unprestigious institutions (usually located in poorer regions of the country). On the other hand, their narratives reveal connections and meeting points between academic work and other social arenas, usually located 'outside' of universities.

The second trend we identified was the close connection, on at least two levels, between the metaphors that these women scientists use and matters of care. In their narratives, the significant borderlands that these women scientists occupy offer them scenarios in which to connect their research with social struggles, regional issues and community work, connections that are intended to promote social transformation. In this sense, their research has the ultimate goal of repairing life in communities, and is therefore closely associated with activism. Through their research, these women scientists become scientists with communities; using Puig de la Bellacasa's (2012) words, when thinking with others they perform care. However, this repairing impulse towards social transformation goes unrecognized within the scientific field. It does not always translate into the logics of science and so, as with other caring practices, it is invisible to, and on occasion not recognized by, the metrics of the system.

On other occasions, however, according to their narratives, the practices through which these women scientists perform matters of care in the Colombian scientific field are strongly recognized. As mentioned above, when these women scientists situate themselves in particular significant borderlands, and from there think with care, they also embody the current organizational and operational ideal of the universities, and therefore the academic and scientific field; that is, the efficient articulation between teaching, research and service. Thus, this borderland self-positioning involves simultaneously a connection with the 'outside' of the field, and, in a way, a reification of the scientific field logics. It remains unanswered whether this ambivalence represents a challenge or a barrier to achieving social transformation and so to building, in Sandra Harding's words (1986), a successor science.

In affirming that a borderland positioning within the scientific field, and the ethos of care that it involves, provides the basic elements for the articulation of teaching, research and service as the central axis of the contemporary university, this raises two main questions that we would like to pose as a way to close and open up this paper. First, under which conditions of possibility would the ethos of care cease to be marginal? And second, what would be the implications of a potential co-optation of the ethos of care by particular neoliberal logics and practices, which articulate research, teaching and service as a way in which to maximize the use of resources in contemporary universities?

\section{REFERENCES}

Anzaldúa, G. (1987). Borderland/La Frontera. The new mesti$z a$. San Francisco, CA: Aunt Lute.

Arango Gaviria, L. G. (2011). El trabajo de cuidado ¿servidumbre, profesión o ingeniería emocional? In L. G. Arango Gaviria \& P. Molinier (Eds.), El trabajo y la ética del cuidado (La Carreta, pp. 91-109). Medellín.

Archila Neira, M. (2003). Idas y venidas. Vueltas y revueltas. Protestas sociales en Colombia 1958 - 1990 (Universida). Bogotá, Colombia.

Blasquez Graff, N. \& Flores, J. (n.d.). Ciencia, tecnología y género en Iberoamérica (Centro de .). México, D.F.

11 It is to say that these findings though are at the core of the scientific practice narrated by the women scientists we studied, it is not exclusive neither essential to their marks. We understand their marks as a privileged entrance to comprehend and make visible the way the scientific field is configured in places like Colombia. 
Bourdieu, P. (1997). Razones prácticas (Anagrama). Barcelona, España.

Bourdieu, P. (2008). Homo academicus. Buenos Aires, DF: Siglo XXI Editores.

Carrasco, C. (2001). La sostenibilidad de la vida humana: ¿Un asunto de mujeres? Mientras Tanto, (82), 43-70.

Castro Romero, V. N. (2011). El trabajo de cuidado y las mujeres aseadoras de la Universidad Nacional de Colombia. In L. G. Arango Gaviria \& P. Molinier (Eds.), El trabajo y la ética del cuidado (La Carreta, pp. 257-273). Medellín.

Daza-Caicedo, S. (2010). Las mujeres en el SNCTI. Balance de una década en condiciones diferentes. In M. Salazar \& et.al (Eds.), Indicadores de Ciencia y tecnología. Bogotá, Colombia: Observatorio Colombiano de Ciencia y Tecnología.

Fernández Ruiz, L. (2006). Género y Mujeres académicas: ¿hasta dónde la equidad? In Ciencia, Tecnología y Género en Iberoamérica, Monografias 29 (CSIC, pp. 55-66). Madrid.

Foucault, M. (1994). La ética del cuidado de sí como práctica de la libertad. In Estética, ética y hermenéutica. Obras Esenciales, Volumen III (Paidos Bás, pp. 393-416). Barcelona, España.

Fox-Keller, E. (1985). Reflections on Gender and Science. New York, NY: Yale University Press.

García Dauder, S. (2005). Psicología y Feminismo. Historia olvidada de mujeres pioneras en Psicologia (Narcea Edi.). Madrid.

Haraway, D. (2004). Testigo_Modesto@Segundo_Milenio. HombreHembra $\bigodot_{-}$Conoce_Oncoratón ${ }^{\circledR}$. Barcelona, España: Editorial UOC.

Haraway, D. (2004). A Manifesto for Cyborgs: Science, Technology, and Socialist Feminism in the 1980s. In D. Haraway (Ed.), The Haraway Reader (pp. 7-45.). New York, NY: Routledge.

Haraway, D. (1988). Situated Knowledges: The Science Question in Feminism and the Privilege of Partial Perspective. Feminist Studies, 14(3), 575-599.

Harding, S. (1986). The Science Question in Feminism. New York, NY: Cornell University Press.

Leininger, M. (1996). Culture Care Theory, Research, and Practice. Nursing Science Quarterly, 9(2), 71-78, available via: http://dx.doi.org/10.1177/089431849600900208

Magollón Porales, C. (2004). Pioneras españolas en las ciencias (Consejo Su). Madrid.

McKenzie-Bassant, C. (2007). Lesbian Teachers Walking the Line between Inclusion and Exposure. International Journal of Art \& Design Education, 26(1), 54-62, available via: http://dx.doi.org/10.1111/j.1476-8070.2007.00510.x

Mikkola, M. (2006). Elizabeth Spelman, Gender Realism, and Women. Hypatia, 21(4), 77-96, available via: http://dx.doi. org/10.1111/j.1527-2001.2006.tb01129.x

Molinier, P. (2011). Antes que todo el cuidado es un trabajo. In L. G. Arango Gaviria \& P. Molinier (Eds.), El trabajo y la ética del cuidado (La Carreta, pp. 45-64). Medellín.

Molinier, P. (2012). El trabajo de cuidado y la subalternidad. In Catedra Inaugural - Posgrados en Estudios de Género - 1 de marzo de 2012. Bogotá, Colombia: Universidad Nacional de Colombia.

Morse, J., Solberg, S., Neander, W., Bottorff, J. \& Johnson, J. (1990). Concepts of caring and caring as a concept. Advances in Nursing Science, 13(1), 1-14.
Mosquera Rosero-Labbé, C. (2006). Pluralismos epistemológicos: hacia la valorización teórica de los saberes de acción. Una reflexión desde la intervención social a la población afrocolombiana desplazada. Palimpsesto, 5, 262-276.

Mosquera Rosero-Labbé, C. (2011). Emoción, razón y “proceso civilizatorio": aproximaciones desde los procesos de atención psicosocial de personas desplazadas por el conflicto armado interno colombia. In L. G. Arango Gaviria \& P. Molinier (Eds.), El trabajo y la ética del cuidado2 (La carreta, pp. 275-294). Medellín, Colombia.

Observatorio colombiano de Ciencia y Tecnología. (2011). Indicadores de Ciencia y Tecnología. Bogotá, Colombia: Observatorio colombiano de Ciencia y Tecnología.

Pérez Sedeño, E. (2011). Mujeres y pioneras en las ciencias: Una Mirada a la realidad iberoamericana. In Ciência, Tecnología e Gênero. Abordagens iberoameicanos (UTPFR, pp. 213-232). Curitiba.

Pérez-Bustos, T., Olarte Sierra, M. F. \& Diaz del Castillo, A. (forthcoming). Working with care: experiences of invisible women scientists practicing forensic genetics in Colombia. In E. Medina, I. Marques \& C. Holmes (Eds.), Beyond Imported Magic: Studying Science and Technology in Latin America. Cambridge, MA: MIT Press. (in Press)

Platt, L., Wall, M., Rhodes, T., Judd, A., Hickman, M., Johnston, L. G. \& Sarang, A. (2006). Methods to recruit hard-to-reach groups: comparing two chain referral sampling methods of recruiting injecting drug users across nine studies in Russia and Estonia. Journal of Urban Health, 83(7), 39-53.

Puig de la Bellacasa, M. (2011). Matters of care in technoscience: Assembling neglected things. Social Studies of Science, 41(1), 85-106, available via: http://dx.doi. org/10.1177/0306312710380301

Puig de la Bellacasa, M. (2012). "Nothing comes without its world": thinking with care. The Sociological Review, 60(2), 197-216, available via: http://dx.doi.org/10.1111/j.1467954X.2012.02070.x

Rhoton, L. A. (2011). Distancing as a Gendered Barrier. Understanding Women Scientists' Gender Practices. Gender \& Society, 25(6), 696-716.

Schiebinger, L. (1999). Has Feminism Changed Science? Boston, MA: Harvard University Press.

SCImago. (2012). Ranking Iberoamericano SIR 2012. (S.R.Group, Ed.). SCImago Institutions Ranking. Retrieved August 30, http://www.scimagoir.com/pdf/SIR\%20Iber\%202012.pdf

Tovar, P. (2006). Indicadores nacionales de género, ciencia y tecnología. In ICANH (Ed.), Memorias seminario: Las mujeres colombianas en el sistema de ciencia y tecnología: obstáculos y logros. Bogotá.

Vessuri, H. \& Canino, M. V. (2006). Igualdad entre géneros e indicadores de ciencia en Iberoamérica. In R. (Comp. . GUBER (Ed.), El Estado de la Ciencia. Principales Indicadores de Ciencia y Tecnología Iberoamericanos/ Interamericanos (RICyT). Buenos Aires, DF.

Williams, C. L. (2013). The Glass Escalator, Revisited: Gender Inequality in Neoliberal Times. Gender \& Society, 0891243213490232-, available via: http://dx.doi. org $/ 10.1177 / 0891243213490232$ 